\title{
A new Late Permian paleomagnetic pole for stable South America: The Independencia group, eastern Paraguay
}

\author{
Augusto E. Rapalini ${ }^{1}$, Sabrina Fazzito ${ }^{1}$, and Delio Orué ${ }^{2}$ \\ ${ }^{1}$ INGEODAV, Depto. Cs. Geológicas, FCEyN, Univ. Buenos Aires, Pabellón 2, Ciudad Universitaria, C1428EHA, Buenos Aires, Argentina \\ ${ }^{2}$ Universidad Nacional de Asunción, Paraguay
}

(Received December 20, 2005; Revised April 8, 2006; Accepted April 25, 2006; Online published November 8, 2006)

\begin{abstract}
The Late Permian segment of the South American apparent polar wander path (APWP) is poorly defined and further paleomagnetic efforts on suitable rocks of such age from stable areas of South America are needed. A study was carried out on the Late Permian Independencia Group, which is discontinuously exposed along Eastern Paraguay and consists of several hundred meters of flat lying continental white, pink and reddish sandstones and siltstones, deposited on the western margin of the Paraná basin. Thirteen sites ( 83 samples) were collected on the top unit of the Group (the latest Permian Tacuary Fm) from outcrops distributed over 1000 square kms. Detailed $\mathrm{AF}$ and thermal demagnetization permitted the isolation of within-site consistent characteristic remanence in eleven sites, being generally hematite the main carrier of the remanence. Excluding one outlier, a paleomagnetic pole was computed by averaging 10 virtual geomagnetic poles of mixed polarities ( 6 reversed, 4 normal), yielding a position at: $80.7^{\circ} \mathrm{S}, 7.0^{\circ} \mathrm{E}, \mathrm{A} 95: 6.6^{\circ}$. The new pole may be considered key for a better definition of the South American APWP by filling a gap between a relatively reliable Early Permian and a poorly defined Early-Middle Triassic groups of poles.
\end{abstract}

Key words: Paleomagnetism, South America, Gondwana, apparent polar wander path, paleogeography.

\section{Introduction}

The South American apparent polar wander path (APWP) for the Late Paleozoic and Early Mesozoic is far from being accurately defined (e.g. Van der Voo, 1993; McElhinny and McFadden, 2000). Different kinds of problems contribute to this, i.e. old results obtained with methodologies no longer considered reliable, innacurate dating of both rocks and magnetizations and a small database. A large portion of the results still used to compute the South American path were obtained in the sixties and seventies with old-fashioned blanket demagnetization techniques with no vectorial analysis. Although numerous studies have been performed in the last two decades in South America with up-to-date methodologies and standards, only a handful of them were aimed at improving the definition of the Late Paleozoic-Early Mesozoic segment of its APWP. Much more effort has been devoted to tectonic studies unravelling the orogenic processes associated with the Andean evolution. Since most studies have been performed on rocks of the Andean chain, their utility in defining the APWP has been frequently questioned and in many cases it is null. Even paleomagnetic data coming from areas relatively far from the main Andean chain have occasionaly been labeled as suspect of being affected by Andean tectonic processes (i.e., tectonic rotations, see for instance Geuna and Escosteguy, 2004). The above mentioned arguments point to the need of new systematic efforts to

Copyright (c) The Society of Geomagnetism and Earth, Planetary and Space Sciences (SGEPSS); The Seismological Society of Japan; The Volcanological Society of Japan; The Geodetic Society of Japan; The Japanese Society for Planetary Sciences; TERRAPUB obtain reliable paleomagnetic information from rocks well far from the South American continental margin in order to better define or re-define the available APWP for South America.

The Late Paleozoic to Early Mesozoic is a time of significant controversies regarding the use of paleomagnetic data in global paleoreconstructions. Since Irving (1977) first proposed a Permian to Triassic Pangea configuration radically different from that globally accepted for the Early to Middle Jurassic (Wegener's Pangea), the controversy has not been solved. The lack of consistency of Permian to Triassic paleomagnetic poles for Laurussia and Gondwana in a typical Wegener's reconstruction of Pangea (Pangea A) was interpreted by Irving (1977), and other authors afterwards, as evidence of a significantly different Pangea reconstruction (Pangea B) for that period. The need of over three thousand kilometers of dextral shear between Laurussia and Gondwana in the Triassic to change from one configuration into the other, for which the geological evidence is at least elusive, has suggested many authors that the problem must reside in the paleomagnetic data. Problems arising from an unreliable database, both in the data itself as in the age assignment have been proposed as a source of the discrepancy (see McElhinny and McFadden, 2000 and references therein). Van der Voo and Torsvik (2001), on the other hand, have questioned the validity of the GAD (geocentric axial dipole) hypothesis for the entire period as a mean of solving the discrepancy. However, this explanation has been ruled out by Muttoni et al. (2003). No matter which explanation is preferred to account for the discrepancy, it seems that a better paleomagnetic database for the different continents 


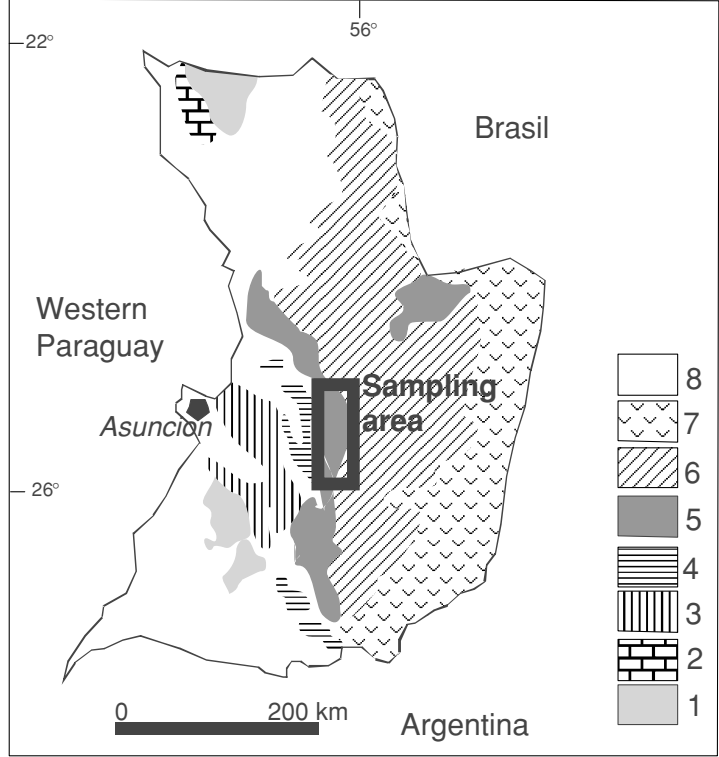

Fig. 1. Geologic sketch of Eastern Paraguay and location of the sampling area. 1. Precambrian igneous and metamorphic basement, 2. Precambrian or Cambrian calcareous rocks, 3. Ordovician to Devonian siliciclastics, 4. Late Carboniferous to Early Permian glacigenic sediments (Coronel Oviedo Formation), 5. Late Permian continental sediments (Independencia Group), 6. Jurassic continental sediments (Misiones Formation), 7. Early Cretaceous volcanics, 8. Undifferentiated Cenozoic rocks. (modified from Orué, 1996).

integrating Gondwana and Laurussia is an unavoidable prerequisite for more definitive tests.

A new latest Permian paleomagnetic pole is presented in this contribution for stable areas of South America. This permits a better definition of the South American Late Paleozoic path. A preliminary comparison of it with the Laurentian database confirms a significant disagreement between both databases in a Pangea A reconstruction, favouring the alternative Pangea B model.

\section{Geologic Background}

The Independencia Group consists in around 400 meters of continental reddish to pink, grayish and white sandstones and siltstones, with minor intercalations of claystones and limestones toward the top of the succesion (Harrington, 1950; Orué, 1996). It constitutes part of the sedimentary infill of the large Paraná basin (e.g. Eyles et al., 1995), being separated from the Chaco-Paraná basin by the Asunción arch. It is discontinuously exposed along large areas of Eastern Paraguay (Fig. 1) and rests upon the Late Carboniferous-Early Permian glacigenic sediments of the Coronel Oviedo Fm. Fossil remains in the Independencia Group are scarce with limited chronostratigraphic resolution (Putzer, 1962 in Orué, 1996). On the basis of this evidence and stratigraphic considerations it has been correlated with similar units in Brasil (i.e. Rio do Rastro Fm.) which are better determined as Late Permian (Lopez Gamundi et al., 1994). Exposures of the Independencia Group are generally limited to road-cuts and quarries due to its subhorizontal attitude, very low topographic relief and extensive cover by vegetation.

The Independencia Group has been subdivided into two units: the San Miguel and Tacuray Formations. The lower unit, the San Miguel Formation, has been recognized both in outcrops and wells and is mainly composed of fine to medium grain sandstones assigned to deltaic to coastal plain environments (Orué, 1996). Conformably on top of this is the Tacuary Formation, which is in turn overlain by the Mesozoic Misiones Formation. According to well data the thickness of the Tacuary formation may reach up to 200 meters. It shows a wider range of lithologies with predominance of fine grain sandstones and siltstones. Subordinate

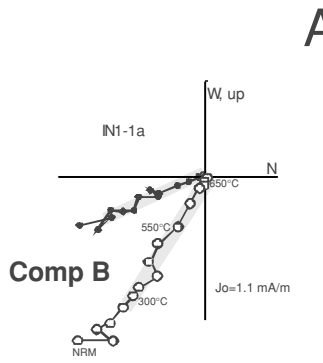

A

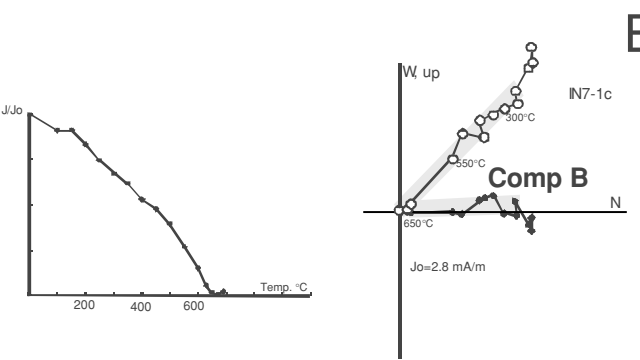

B
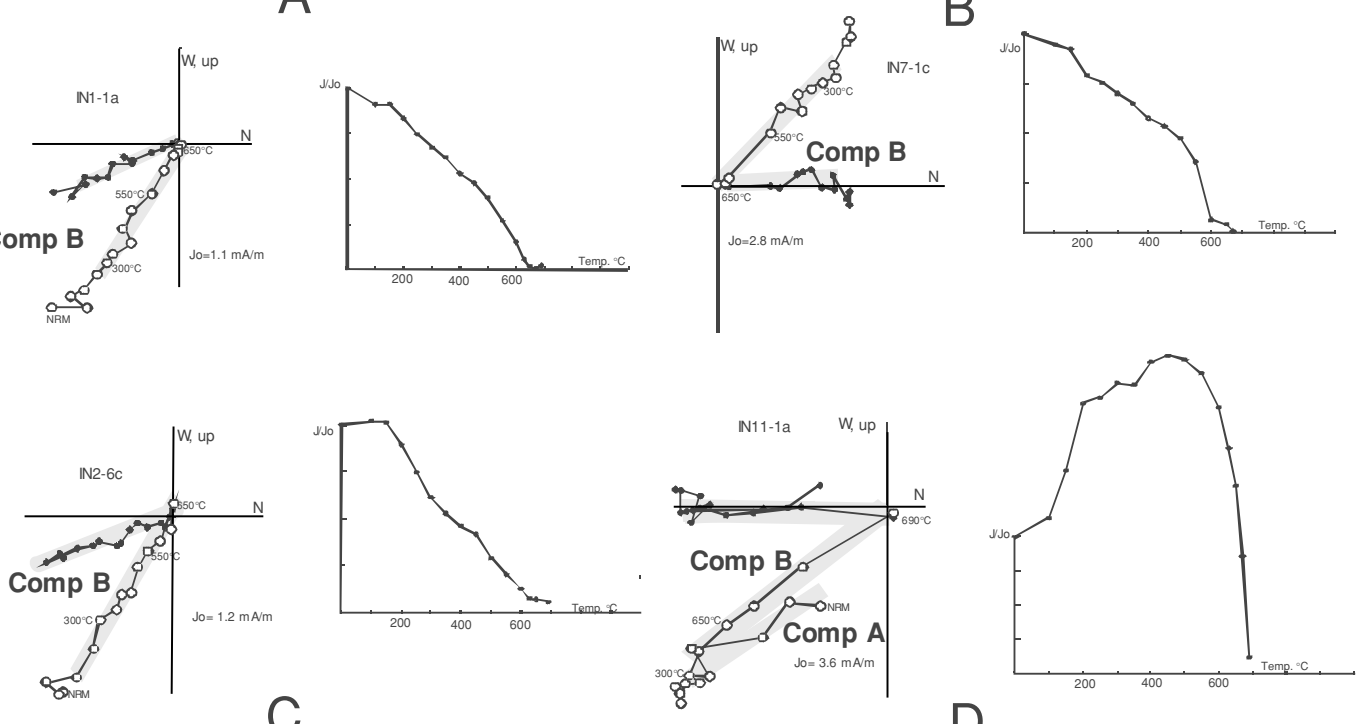

$\mathrm{D}$

Fig. 2. Typical demagnetization behaviour of samples from the Independencia Group represented by vectorial (As-Zijderveld) plots and normalized demagnetization curves. Open (full) symbols in the vectorial diagrams represent projections onto the vertical (horizontal) plane. Grey bands indicate approximate directions of magnetic components. More references in the text. 


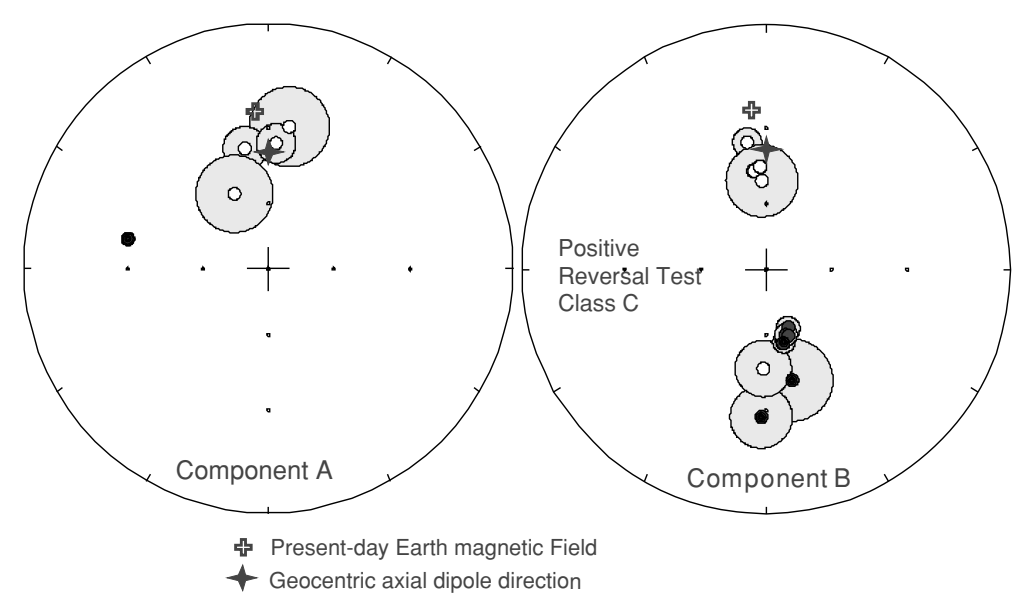

Fig. 3. A. Component A mean site directions for the Independencia Group. B. idem for component B. Open (full) symbols correspond to negative (positive) inclinations. Shaded circles are the $\alpha 95$ for each site direction. More references in the text and Table 1 .

occurrence of oolitic limestones and calcareous sandstones has been reported. Its deposition has been interpreted as occurrying in a coastal environment with variable contributions from fluvial and lacustrine processes (Orué, 1996).

\section{Sampling and Laboratory Procedures}

Eighty-three samples (13 sites) were collected with a portable drill over an area of more than $1000 \mathrm{~km}^{2}$ on the top unit of the Independencia Group (the Tacuary Fm.). Samples were mostly from reddish to brownish fine grain sandstones and siltstones. Precise stratigraphic relations between sites are generally impossible to determine due to isolation of most outcrops and long distances between sampling localities (Fig. 1). Six to seven $2.54 \mathrm{~cm}$ in diameter samples were generally collected at each site, which were in turn sliced into $2.2 \mathrm{~cm}$ long specimens at the laboratory. Samples were submitted to standard AF and thermal demagnetizations. In general, thermal demagnetization was more efficient than AF treatment, with the exception of sites IN12 and IN13 for which both methods yielded similar results. Most samples were submitted to thermal treatment in 16 steps up to temperatures of $690^{\circ} \mathrm{C}$. Measurement of remanence was performed with a DC-Squids criogenic magnetometer ( $2 \mathrm{G}$ enterprise). After each step, possible changes in magnetic mineralogy were controlled by measurement of bulk susceptibility with a Bartington MS-2 susceptibilimeter. Magnetic components were isolated individually and determined by principal component analysis (Kirschvink, 1980). Maximum angular deviation (MAD) values over $15^{\circ}$ implied rejection of the component. $86 \%$ of components presented MAD values under $10^{\circ}$.

\section{Results}

Representative behaviours of samples from the Independencia Group are illustrated in Fig. 2. A well-defined characteristic magnetic component was determined in eleven out of thirteen sites. Samples from sites IN4 and IN6 presented unstable behaviour. In a few sites (IN1, IN10, IN11, IN12, IN13) a low temperature component (Component A) was isolated with a general ressemblance to the present day Earth Magnetic Field direction (Fig. 3A). The characteris-

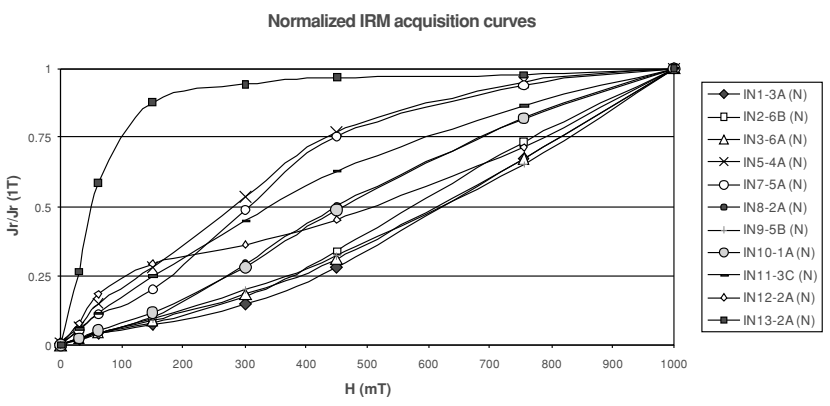

Fig. 4. Normalized isothermal remanent magnetization (IRM) acquisition curves for the Independencia Group samples. Note that in most cases the contribution of ferrimagnetic phases is negligible. More references in the text.

tic component (Comp. B) showed linear decay towards the origin and unblocking temperatures generally in the range of hematite $\left(600-690^{\circ} \mathrm{C}\right.$, Fig. 2). In a few sites the possible presence of magnetite with a similar magnetic direction was observed (Fig. 2B). The magnetic mineralogy was confirmed by isothermal remanent magnetization (IRM) acquisition curves (Fig. 4) performed on one specimen per site. Each specimen was submitted to pulse direct magnetic fields of 30,60, 150, 300, 450, 755 and $1000 \mathrm{mT}$. Figure 4 shows that with the exception of IN-13 and IN-12, and to a minor extent IN-5, all sites have concave upwards curves at low magnetic fields, indicative of no significant presence of ferrimagnetic (magnetite, titanomagnetite) minerals. On the other hand, site IN-13 shows a dominant ferrimagnetic carrier with very subordinate contribution of an antiferromagnetic fraction.

In general, samples showed a good to excellent withinsite consistency of directions (Table 1). Six sites presented reversed polarity while other four showed normal directions. One site (IN-12) presented an anomalous direction suggesting either a transitional field or an incorrect stratigraphic assignment of the sampled rocks (i.e. it resembles an Early Paleozoic direction). The remaining 10 sites pass a reversal test (McFadden and McElhinny, 1990) with qualification C. Since all sampled rocks are subhorizontal no bedding correction was applied to the remanence data. 
Table 1. Mean site directions for the characteristic remanence (Component B) of the Independencia Group. $n$ : number of samples used to compute the mean, Dec: declination; Inc: inclination; $\alpha 95$ : Fisher's angle of confidence.

\begin{tabular}{lcccccc}
\hline \multicolumn{1}{c}{ Site } & $n$ & $\begin{array}{c}\text { Dec } \\
\end{array}$ & & $\begin{array}{c}\text { Inc } \\
\left({ }^{\circ}\right)\end{array}$ & \multicolumn{1}{c}{$\alpha 95$} & \multicolumn{2}{c}{ VGP } \\
\hline IN-1 & 4 & 166.8 & 56.1 & 3.2 & 74.0 & 345.3 \\
IN-2 & 4 & 159.6 & 61.0 & 5.3 & 66.3 & 343.6 \\
IN-3 & 5 & 163.1 & 58.8 & 4.9 & 69.9 & 344.3 \\
IN-5 & 6 & 351.5 & -34.6 & 5.3 & 79.9 & 70.5 \\
IN-7 & 3 & 353.1 & -45.9 & 2.9 & 83.5 & 14.2 \\
IN-8 & 4 & 356.7 & -44.4 & 2.6 & 86.9 & 18.0 \\
IN-9 & 4 & 357.3 & -50.2 & 14.8 & 83.9 & 325.8 \\
IN-10 & 6 & 166.2 & 56.1 & 4.8 & 73.6 & 346.4 \\
IN-11 & 5 & 167.0 & 40.1 & 15.7 & 77.9 & 42.9 \\
IN-12* & 8 & 181.6 & -45.8 & 11.3 & -37.5 & 305.4 \\
IN-13 & 4 & 181.9 & 27.7 & 10.6 & 79.3 & 133.5 \\
\hline *Excluded for computing the pole. \\
Palleong $\left({ }^{\circ} \mathrm{E}\right)$ \\
\hline
\end{tabular}

Paleomagnetic Pole: IN, $80.7^{\circ} \mathrm{S}, 7.0^{\circ} \mathrm{E}, \mathrm{A} 95: 6^{\circ}, \mathrm{N}=10$ sites.

Table 2. Results of the isothermal remanent magnetization experiment used to test potential inclination shallowing of the natural remanence. $\mathrm{I}_{\text {applied }}$ : inclination of the applied magnetic field respect to the bedding plane; IIRM: inclination of the isothermal remanence respect to the bedding plane (measured as the average of 4 or 5 consecutive steps up to 1 Tesla); $\alpha 95$ : Fisher's angle of confidence for the averaged IRM direction. More references in the text.

\begin{tabular}{cccc}
\hline Site & $\mathrm{I}_{\text {applied }}\left({ }^{\circ}\right)$ & $\mathrm{I}_{\text {IRM }}\left(^{\circ}\right)$ & $\alpha 95\left(^{\circ}\right)$ \\
\hline IN-1 & 43.8 & 44.5 & 3.1 \\
IN-2 & 43.6 & 42.9 & 2.5 \\
IN-3 & 40.6 & 45.2 & 2.3 \\
IN-5 & 41.6 & 37.2 & 2.7 \\
IN-7 & 44.6 & 48.8 & 2.2 \\
IN-8 & 42.0 & 45.7 & 2.6 \\
IN-9 & 39.9 & 47.6 & 5.5 \\
IN-10 & 43.8 & 41.2 & 2.0 \\
IN-11 & 43.1 & 44.9 & 3.9 \\
IN-12 & 43.8 & 51.9 & 9.7 \\
IN-13 & 43.8 & 41.7 & 2.7 \\
\hline
\end{tabular}

Paleomagnetic data from clastic sedimentary rocks are often suspect of suffering from inclination shallowing due to post-depositional compaction. When this occurs a correction of the remanence inclination must be applied. Postdepositional compaction tends to rotate the remanence vector towards the bedding plane with no change in declination. A rapid test of significant inclination shallowing consists in applying IRM along an axis that forms a $45^{\circ}$ angle with the bedding plane (Tan and Kodama, 2002; Tan et al., 2002). If no inclination shallowing has occurred, then no significant deflection of the acquired IRM is expected. The IRM acquisition experiments illustrated in Fig. 4 were done in this way in order to define if any correction of the remanence vector for compaction is necessary for the Independencia Group. Table 2 presents the results obtained after this experiment. A mean isothermal remanence direction was obtained by averaging the remanence vector generated through the highest four stages (300, 450, 755 and 1000 $\mathrm{mT}$ ) in order to preferably compute the domains with higher coercive forces and to minimize experimental errors. The
Table 3. Selected paleomagnetic poles for South America between the earliest Permian (295 Ma) and the Middle Triassic (240 Ma). Q: quality factor of Van der Voo (1990), with a maximum possible value of seven. References: 1: Pascholati and Pacca (1976); 2: Sinito et al. (1979); 3 . Tomezzoli and Vilas (1999); 4. Embleton (1970); 5: Tomezzoli (2001); 6: Valencio et al. (1977); 7: this paper; 8: Conti and Rapalini (1990); 9: Ernesto (2005); 10: Hargraves (1978); 11: Creer et al. (1970).

\begin{tabular}{lccccccc}
\hline Geologic Unit & \multicolumn{3}{c}{ Code } & Pole lat Pole Long & A95 & Ag & Q Ref. \\
& & $\left({ }^{\circ} \mathrm{S}\right)$ & $\left({ }^{\circ} \mathrm{E}\right)$ & $\left({ }^{\circ}\right)$ & $(\mathrm{Ma})$ & \\
\hline Itarare Gr. 1 & $\mathrm{IT1}$ & 56.7 & 350.6 & 4.0 & 295 & 5 & 1 \\
La Colina Fm & $\mathrm{LC}$ & 49.0 & 343.0 & 8.0 & 295 & 4 & 2 \\
Tunas Fm & $\mathrm{TU}$ & 62.7 & 16.6 & 5.1 & 290 & 6 & 3 \\
Los Colorados Inf & $\mathrm{CO} 1$ & 60.0 & 358.0 & 5.0 & 290 & 4 & 4 \\
Itarare Gr. 2 & $\mathrm{IT} 2$ & 60.3 & 29.5 & 4.0 & 285 & 5 & 1 \\
Pillahuinco Fm & $\mathrm{PH}$ & 74.8 & 27.0 & 5.0 & 280 & 5 & 5 \\
Paganzo Gr. & $\mathrm{PG}$ & 78.0 & 249.0 & 3.0 & 275 & 3 & 6 \\
Independencia Gr & $\mathrm{IN}$ & 80.7 & 7.0 & 6.6 & 260 & 5 & 7 \\
Choique Mahuida Fm & $\mathrm{CH}$ & 75.0 & 244.0 & 10.2 & 250 & 4 & 8 \\
Amana Fm & $\mathrm{AM}$ & 83.0 & 317.0 & 8.0 & 250 & 3 & 6 \\
Alto Paraguay volcanics & $\mathrm{AP}$ & 78.0 & 319.0 & 6.0 & 245 & 5 & 9 \\
Guyana dikes & $\mathrm{GY}$ & 63.8 & 208.9 & 10.5 & 245 & 2 & 10 \\
El Nihuil lavas & $\mathrm{NH}$ & 81.0 & 282.0 & 6.0 & 240 & 3 & 11 \\
\hline
\end{tabular}

$\alpha_{95}$ values presented in the table correspond to this average. Due to its lower coercivity values, site IN-5 also included the $150 \mathrm{mT}$ stage. IN-12 showed a large dispersion of values turning this experiment useless in this case. For the remaining samples no significant or systematic inclination shallowing is observed. The inclination values observed for the IRM are generally equal to the applied field within error. These results suggest that the natural remanent magnetization of the Independencia Group is a reliable record of the paleomagnetic field.

\section{Interpretation and Conclusions}

The dual polarity remanence defined in our results suggests a Late Permian, post-Kiaman age for the Independencia Group. According to the most recent Geologic Time Scale (Gradstein et al., 2004), the Kiaman or Late Paleozoic Reverse Superchron ended around $265 \mathrm{Ma}$ and was followed by a period of several polariry reversals until around $255 \mathrm{Ma}$. This and the most likely stratigraphic age for the Tacuary Formation suggest a magnetization age close to $260 \mathrm{Ma}$, in the late Guadalupian or early Lopingian.

Each site mean direction has been converted into a virtual geomagnetic pole (VGP, Table 1) and the mean of the ten VGPs is considered the best estimate of the paleomagnetic pole for the Independencia Group: IN: $80.7^{\circ} \mathrm{S}, 7.0^{\circ} \mathrm{E}, \mathrm{A} 95$ : $6.6^{\circ}, \mathrm{N}: 10$ sites.

IN is a reliable Late Permian pole from stable South America. Figure 5 shows IN together with other Late Paleozoic to Early Triassic South American poles. These (Table 3) have been chosen following recent selections by Tomezzoli (2001), Geuna and Escoteguy (2004) and Vizán et al. (2004). Quality factor (Q) from Van der Voo (1990) is also included in Table 3 to get a glimpse on the reliability of the available data for establishing the South American APWP. South American paleomagnetic data suffer from several limitations, not the least the fact that a large part of the data comes from the Andean orogen, where ex- 


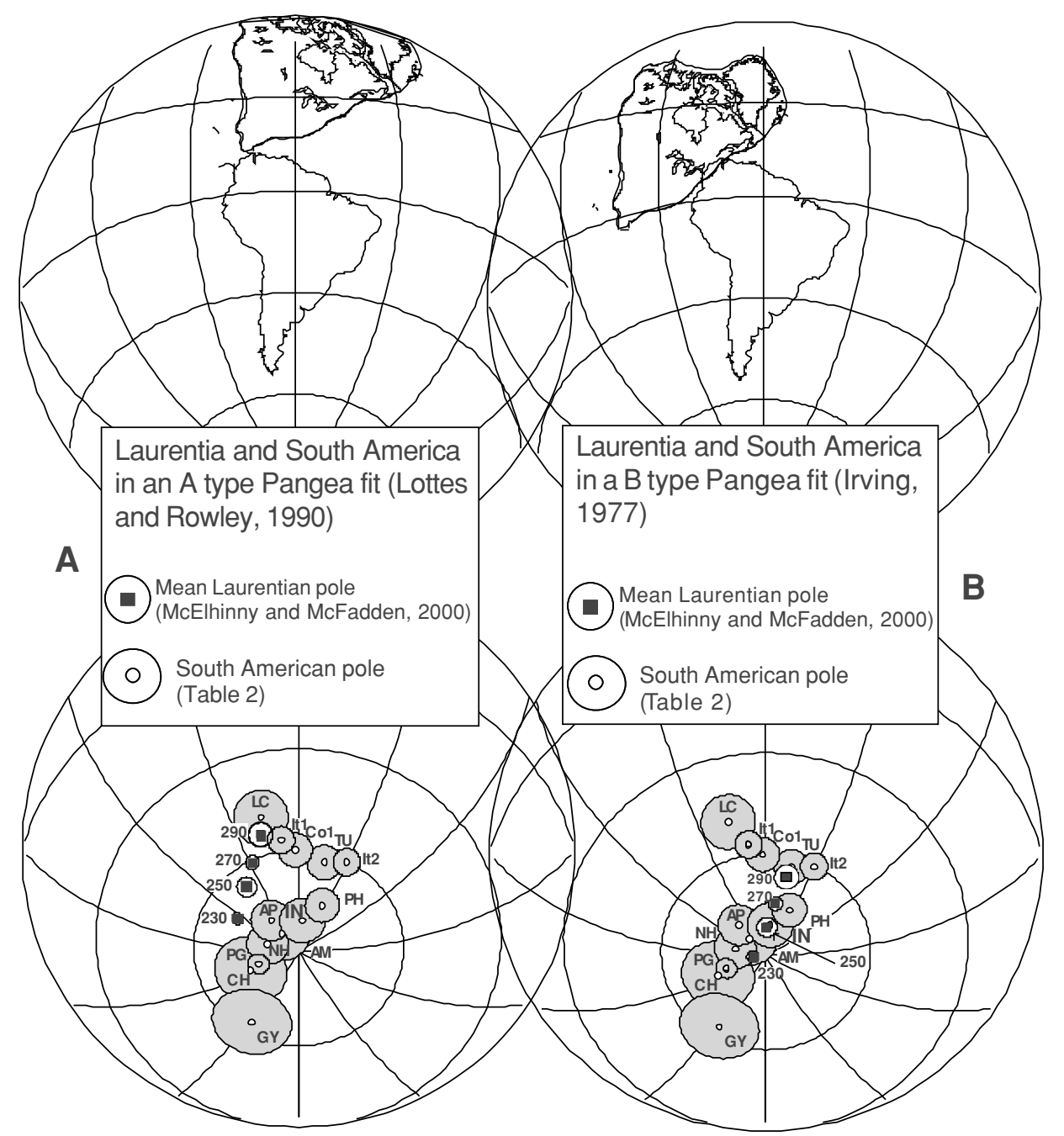

Fig. 5. A. Relative positions of Laurentia and South America according to an A type Pangea fit in South American coordinates (54. $7^{\circ} \mathrm{N}, 43.0^{\circ} \mathrm{E}$, rot: $+29.8^{\circ}$ ), following rotation parameters of Lottes and Rowley (1990), and distribution of Permian to Triassic mean poles for Laurentia (McElhinny and McFadden, 2000) and selected poles for South America (Table 3). Note large disagreement of poles. Labels for the poles correspond to those of Table 3, and numbers indicate mean age in Myr for the Laurentia mean poles. B. Relative positions of Laurentia and South America according to a B-type Pangea fit (Irving, 1977) in South American coordinates $\left(48.8^{\circ} \mathrm{N}, 34.0^{\circ} \mathrm{E}\right.$, rot: $\left.+49.8^{\circ}\right)$ and distribution of Permian mean poles for Laurentia and selected poles for South America. Note good agreement between Laurentian and South American poles. More references in the text.

posures and geological records are generally the best, but where potential tectonic rotations affecting the paleomagnetic poles invalidate their use in constructing the APWP. As can be seen in Table 3, paleomagnetic data for the Early Permian (295-275 Ma) show significantly better Q values than those for the latest Permian and early Triassic (250$240 \mathrm{Ma})$. The only exception is the paleomagnetic pole for the Paganzo Group (Valencio et al., 1977) for which Geuna and Escoteguy (2004) have recently suggested the possibility of being affected by undetected tectonic rotations. Therefore, we have conservatively considered this pole to fail Van der Voo's criterium $\mathrm{N}^{\circ}$ 5. The same uncertainty on its tectonic coherence applies to the Amaná Fm. pole (Valencio et al., 1977) of earliest Triassic age. Furthermore, all poles with ages between 295 and $265 \mathrm{Ma}$ are expected to present only reverse polarity as they would fall within the Kiaman reverse superchron (Gradstein et al., 2004 and references therein), which means that the Early Permian poles can reach a maximum $\mathrm{Q}=6$, while those younger could theoretically reach $\mathrm{Q}=7$. This stresses the much better def- inition of the Early Permian section of the South American APWP compared to the latest Permian-Early Triassic one. On the other hand the Late Permian to Early Triassic data do not pass Van der Voo's criterium $N^{\circ} 7$ ("lack of resemblance to younger poles") due to the long accepted very limited APWP of South America during the Mesozoic and Cenozoic (Vilas, 1981; Beck, 1988; etc.).

Our new pole falls between the well defined Early Permian poles and the less reliable Early Triassic ones. Geuna and Escosteguy (2004) have recently cast doubts on the validity of previously proposed Late Paleozoic APWP for South America due to possible undetected crustal block rotations associated to Andean tectonism. This may be the case for some poles frequently used to construct the path (see for instance the anomalous position of the Paganzo Gr. pole in Fig. 5), however, our new pole, that comes from a region not affected by any Andean or post-Paleozoic tectonic disturbance, confirms the generally accepted APWP for South America in the late Paleozoic. Figure 5 suggests a smooth Permian to Triassic path for South Amer- 
ica. A significant change in the South American path is observed at around $290 \mathrm{Ma}$ (see Tomezzoli, 2001 and references therein). After that time the APWP seems to describe a rectilinear trajectory between about 290 and 240 $\mathrm{Ma}$, although, as already mentioned, the Triassic poles are of much lower quality than the Permian ones. A similar rectilinear trajectory during most of the Permian is also evident in the Laurentian path (McElhinny and McFadden, 2000, see also Fig. 5).

Since the first proposal of Irving (1977), a controversy around the paleoreconstruction of the Pangea continents during Permian and Triassic is still under debate. The main problem arises from the lack of consistency of Permian to Triassic paleomagnetic poles for the different Pangea continents when reconstructed into a Wegerner's Pangea. This Pangea called type-A (Morel and Irving, 1981) is however consistent with the Early to Middle Jurassic paleomagnetic data and with paleoreconstructions obtained by closing the present-day oceans (Bullard et al., 1965; Van der Voo, 1993). Many authors have considered several different explanations in order to avoid a dramatic paleogeographic change of the Permian Pangea respect to the Jurassic one (see for instance McElhinny and McFadden, 2000; Van der Voo and Torsvik, 2001). These explanations have generally been based on problems with an unreliable database or a non-dipolar geomagnetic behaviour. However, new studies seem to confirm the discrepancy among the Pangea paleomagnetic poles (e.g. Muttoni et al., 1996; Torcq et al., 1997) and apparently also rule out the geomagnetic alternative (Muttoni et al., 2003). Considering the Permian segment of the South American APWP as a robust one, a comparison was made with the Laurentian counterpart in order to test which Pangea type reconstruction it favours (Fig. 5A and B). When compared to the Laurentian database, our new pole also confirms a Pangea-B configuration between Laurentia and South America for the Late Permian. This reconstruction produces an excellent match in position and age between the mean Laurentian poles of 290, 270 and 250 Ma (McElhinny and McFadden, 2000) with the selected poles for South America (Table 3, Fig. 5B). In particular, our new pole is perfectly consistent with the mean Laurentian pole for the Permian-Triassic boundary. Matching of the 230 Ma with the Triassic poles of South America is hampered by the large dispersion of the latter (see also Vizán et al., 2004). A Pangea-A reconstruction between Laurentia and South America, on the other hand, is clearly inconsistent with the Permian paleomagnetic data (Fig. 5A).

Acknowledgments. Sampling for this study was carried out thanks to a grant of the Argentine Ministry of Foreign Affairs ("Convenio de Cooperación Horizontal"). Further financial support was obtained from a research grant by the Universidad de Buenos Aires (UBACyT X262) and by the CONICET. SIAPD and GMAP programs were utilized in the analysis of paleomagnetic data and paleoreconstructions, respectively. Reviews by R. Trindade and an anonymous reviewer significantly improved the final version of the manuscript.

\section{References}

Beck, M. E. Jr, Analysis of Late Jurassic-Recent paleomagnetic data from active plate margins of South America, Journal of South American Earth Sciences., 1, 39-52, 1988.
Bullard, E. C., J. E. Everett, and A. G. Smith, The fit of continents around the Atlantic, Phil. Trans. Roy. Soc., 258, 41-51, 1965.

Conti, C. and A. E. Rapalini, Paleomagnetismo de la Formacion Choique Mahuida, aflorante en la sierra homónima, provincia de La Pampa, República Argentina. 12th Congreso Geoógico Argentino, San Juan, Argentina, 2, 235-238. 1990.

Creer, K. M., B. J. J. Embleton, and D. A. Valencio, Triassic and PermoTriassic palaeomagnetic data for South America, Earth and Planet. Sci. Lett., 8, 173-178, 1970.

Embleton, B. J. J. Paleomagnetic results for the Permian of South America and a comparison with the African and Australian data, Geophys. J. R. astr. Soc., 21, 105-118. 1970.

Ernesto, M., New Early Triassic Paleomagnetic Pole for South America from the Alto Paraguay Alkaline Province. 2005 Joint Assembly AGU, New Orleans, USA, Abstracts: GP-41A-08, 2005.

Eyles, N., A. Franca, G. Gonzalez Bonorino, C. H. Eyles, and O. López Paulsen, Hydrocarbon-bearing late Paleozoic glaciated basins of southern and central South America, American Association of Petroleum Geologists Memoir, 62, 165-183, 1995.

Geuna, S. and L. D. Escosteguy, Paleomagnetism of the Upper Carboniferous-Lower Permian transition from Paganzo basin, $\mathrm{Ar}$ gentina, Geophys. J. Int., 157, 1071-1089, 2004.

Gradstein, F. M., J. G. Ogg, and A. G. Smith, A Geologic Time Scale 2004, Cambridge University Press, Cambridge, UK, 589 pp., 2004.

Hargraves, R. B. Problems in palaeomagnetic synthesis illustrated by results from Permo-Triassic dolerites in Guyana, Phys. Earth Planet. Inter., 16, 277-284, 1978.

Harrington, H. J., Geología del Paraguay Oriental, Universidad de Buenos Aires, Fac. Cs. Exactas y Naturales, Contribuciones Científicas, Serie E, Geología, 1, 1-88, 1950.

Irving, E., Drift of the major continental blocks since the Devonian, $\mathrm{Na}$ ture, 270, 304-309, 1977.

Kirschvink, J. L., The least-squares line and plane and the analysis of palaeomagnetic data, Geophys. J. R. astr. Soc., 62, 699-718, 1980.

Lopez Gamundi, O., I. Espejo, P. Conaghan, and C. Mc. A. Powell, Southern South America, in Permian-Triassic Pangean Basins and Fold Belts along the Panthalassan margin of western Gondwanaland, edited by J. Veevers and C. Mc. A. Powell, Geological Society of America Memoir, 184, 281-329, 1994.

Lottes, A. L. and D. B. Rowley, Reconstruction of the Laurasian and Gondwanan segments of Permian Pangaea, Geological Society Memoir, 12, 383-395, 1990

McElhinny, M. W. and P. L. McFadden, Paleomagnetism. Continents and Oceans, Academic Press, Internat. Geophys. Series, 73, 386 pp., 2000.

McFadden, P. L. and M. W. McElhinny, Classification of the reversal test in palaomagnetism, Geophys. J. Int., 103, 725-729, 1990.

Morel, P. and E. Irving, Paleomagnetism and the evolution of Pangea, $J$. Geophys. Res., 86, 1858-1872, 1981.

Muttoni, G., D. V. Kent, and J. E. T. Channell, Evolution of Pangea: paleomagnetic constraints from the Southern Alps, Italy, Earth. Planet. Sci. Lett., 140, 97-112, 1996.

Muttoni, G., D. V. Kent, E. Garzanti, P. Brack, N. Abrahamsen, and M. Gaetani, Early Permian Pangea 'B' to Late Permian Pangea 'A', Earth. Planet. Sci. Lett., 215, 379-394. 2003.

Orué, D. Sintese da geologia do Paraguai Oriental, com enfase para o magmatismo alcalino associado, Instituto de Geociencias, Universidad de Sao Paulo, Master Thesis, 163 pp., 1996.

Pascholati, E. M. and I. G. Pacca, Estudo paleomagnético de secçoes do Sub-Grupo Itararé, 29th Cong. Brasil. Geol., Belo Horizonte, 2, 275 $281,1976$.

Sinito, A. M., D. A. Valencio, and J. F. Vilas, Palaeomagnetism of a sequence of Upper Palaeozoic-Lower Mesozoic red beds from Argentina, Geophys. J. R. astr. Soc., 58, 237-247, 1979.

Tan, X. and K. P. Kodama, Magnetic anisotropy and paleomagnetic inclination shallowing in red beds: Evidence from the Mississipian Mauch Chunk Formation, Pennsylvania, J. Geophys. Res., 107(B11), 2311, doi: 10.129/2001JB001636, EPM 9-1/9-17, 2002.

Tan, X., K. P. Kodama, and D. Fang, Laboratory depositional nad compaction-caused inclination errors carried by haematite and their implications in identifying inclination error of natural remanence in red beds, Geophys. J. Int., 151, 475-486, 2002.

Tomezzoli, R. N., Further paleomagnetic results from the Sierras Australes fold and thrust belt, Argentina, Geophys. J. Int., 147, 356-366, 2001.

Tomezzoli, R. N. and J. F. Vilas, Palaeomagnetic constraints on the age of deformation of the Sierras Australis thrust and fold belt, Argentina, Geophys. J. Int., 138, 857-870, 1999. 
Torcq, F., J. Besse, D. Vaslet, J. Marcoux, L. Ricou, M. Halawani, and M. Basahel, Paleomagnetic results from Saudi Arabia and the PermoTriassic Pangea configuration, Earth. Planet. Sci. Lett., 148, 553-567, 1997.

Valencio, D. A., J. F. Vilas, and J. E. Mendia, Paleomagnetism of a sequence of red beds of the middle and the upper sections of Paganzo Group (Argentina) and the correlation of upper Palaeozoic-lower Mesozoic rocks, Geophys. J. R. astr. Soc., 51, 59-74, 1977.

Van der Voo, R., The reliability of paleomagnetic data, Tectonophysics, 184, 1-9, 1990.

Van der Voo, R. Paleomagnetism of the Atlantic, Tethys and Iapetus Oceans, Cambridge University Press, 411 pp., 1993.

Van der Voo, R. and T. Torsvik, Evidence for late Paleozoic and Mesozoic non-dipole fields provides an explanation for the Pangea reconstruction problems, Earth. Planet. Sci. Lett., 187, 71-81, 2001.

Vilas, J. F., Paleomagnetism of South American rocks and the dynamic processes related with the fragmentation of Western Gondwana, in $\mathrm{Pa}$ leoreconstruction of the Continents, edited by M. W. McElhinny and D. A. Valencio, Am. Geophys. Union, Geol. Soc. Am., Geodynamics Series, 2, 106-114, 1981.

Vizán, H., R. Ixer, P. Turner, J. M. Cortés, and G. Cladera, Paleomagnetism of Upper Triassic rocks in the Los Colorados Hill section, Mendoza province, Argentina, Journal of South American Earth Sciences, 18, 4159, 2004.

A. E. Rapalini (e-mail: rapalini@gl.fcen.uba.ar), S. Fazzito, and D. Orué 